\title{
Vancomycin Derivative Inactivates Carbapenem-resistant Acinetobacter baumannii and Induces Autophagy
}

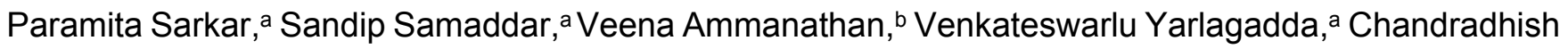
Ghosh, ${ }^{a}$ Manjulika Shukla, ${ }^{c}$ Grace Kaul, ${ }^{c}$ Ravi Manjithaya, ${ }^{b}$ Sidharth Chopra, ${ }^{c}$ and Jayanta Haldar a* 


\section{Table of Contents}

Materials and methods -Page S2

Experimental Section- Page S2

Synthesis and characterisation of compounds Page S2

Biological assays-Page S4

Results- Page S6

References -Page S7

\section{Materials and methods}

All reagents were purchased from Sigma-Aldrich and Spectrochem and used without further purification. All the solvents of reagent grade were purchased from Spectrochem and SD Fine. Chloroform for column chromatography was purchased from SD Fine chemicals and distilled prior to use. HPLC grade acetonitrile was purchased from Spectrochem. Analytical thin layer chromatography (TLC) was performed on E. Merck TLC plates pre-coated with silica gel $60 \mathrm{~F} 254(250 \mu \mathrm{m}$ thickness). Vancomycin derivative was purified by reverse phase HPLC using $0.1 \%$ trifluoroacetic acid (TFA) in water/acetonitrile $(0-100 \%)$ as mobile phase. HPLC analysis was performed on a Shimadzu-LC $8 \AA$ Liquid Chromatography instrument (C18 column, $10 \mathrm{~mm}$ diameter, $250 \mathrm{~mm}$ length) with UV detector monitoring at $254 \mathrm{~nm}$. The NMR spectra were recorded using Bruker AMX-400 $(400 \mathrm{MHz}$ for $1 \mathrm{H})$ spectrometer in deuterated solvents. The chemical shifts $(\delta)$ are reported in parts per million downfield from the peak for the internal standard TMS for ${ }^{1} \mathrm{H}$ NMR. High resolution mass spectra (HR-MS) were obtained using $6538-\mathrm{UHD}$ Accurate Mass Q-TOF LC-MS instrument. TECAN (Infinite series, M200 pro) Plate Reader was used to measure absorbance in biological assays. Quanta 3D FEG, FEI scanning electron microscope was used for SEM imaging and a Zeiss 510 Meta confocal laser-scanning microscope was used for confocal imaging. Bacterial strains, MRSA ATCC 33591, Enterococcal strains, A. baumannii were obtained from ATCC (Rockville, MD) and MTCC. Clinical isolates were obtained from National Institute of Mental Health and Neuro Sciences (NIMHANS) Bengaluru, India and BEI resources. ptfLC3 plasmid (catalog 21074) was purchased from Addgene.

Animals: Six-week old pathogen free Balb/c female mice weighing 20 to $24 \mathrm{~g}$ were used for in vivo studies. The animal experiments were approved by the Institutional Animal Ethics Committee (IAEC) and carried out as per the guidelines of Committee for the purpose of Supervision and Experiments on Animals (CPCSEA), Ministry of Environment and Forests, New Delhi. 


\title{
Experimental Section
}

\author{
Synthesis and characterisation of compounds
}

Synthesis of -Butyl (3-(dimethylamino)propyl)carbamate: $N^{1}, N^{1}$-Dimethylpropan-1,3-diamine ( $4 \mathrm{~g}, 1$ equivalent) was dissolved in $1 \mathrm{M} \mathrm{NaOH}$ solution and (Boc) $)_{2} \mathrm{O}$ ( 4 equivalent) was added to it. The reaction mixture was stirred at room temperature for $10 \mathrm{~h}$. The compound was then extracted into the organic layer using chloroform. The resultant organic solution was evaporated and dried to afford colourless oily tert-butyl (3-(dimethylamino) propyl)carbamate with $70 \%$ yield.

${ }^{1} \mathrm{H}-\mathrm{NMR}\left(400 \mathrm{MHz}, \mathrm{CD}_{3} \mathrm{OD}\right)$ d/ppm: $3.05\left(\mathrm{t},-\left(\mathrm{CH}_{3}\right)_{2} \mathrm{~N}-\mathrm{CH}_{2} \mathrm{CH}_{2}-, 2 \mathrm{H}\right), 2.36-2.31\left(\mathrm{~m},-\mathrm{CH}_{2} \mathrm{CH}_{2}-\mathrm{NH}_{2}, 2 \mathrm{H}\right), 2.23\left(\mathrm{~s},-\mathrm{N}(\mathrm{CH})_{2}, 6 \mathrm{H}\right)$, 1.69-1.61(m, $\left.-\mathrm{CH}_{2} \mathrm{CH}_{2} \mathrm{CH}_{2-}, 2 \mathrm{H}\right), 1.43\left(\mathrm{~s},-\mathrm{CO}-\mathrm{O}-\mathrm{C}\left(\mathrm{CH}_{3}\right)_{3}, 9 \mathrm{H}\right)$. HRMS m/z: $203.1737\left((\mathrm{M}+\mathrm{H})^{+}\right.$observed), 203.1755 (calculated)

Synthesis of 2-Bromo-N-decyl-ethanamide (1a): Decyl amine (2 g, 1 equivalent) was dissolved in $10 \mathrm{~mL}$ of dichloromethane (DCM) and kept at $4{ }^{\circ} \mathrm{C}$ under stirring. $\mathrm{K}_{2} \mathrm{CO}_{3}(1.5$ equivalent) was dissolved in $10 \mathrm{~mL}$ millipore water and added to the decyl amine solution. Bromoacetyl bromide (1.5 equivalent) was then dissolved in $10 \mathrm{~mL}$ of dry DCM and added drop-wise into the reaction mixture at $4^{\circ} \mathrm{C}$, over 30 minutes. The reaction mixture was then allowed to stir at room temperature for $8 \mathrm{~h}$. The product was extracted in organic chloroform layer. The resultant chloroform layer was evaporated under reduced pressure to obtain the pure required product with yield of $97 \%$.

${ }^{1} \mathrm{H}-\mathrm{NMR}\left(400 \mathrm{MHz}, \mathrm{CDCl}_{3}\right.$ ) $\delta / \mathrm{ppm}$ : 6.52 (s, amide -NHCO-, $1 \mathrm{H}$ ), 3.87 (s, - $\left.\mathrm{COCH}_{2} \mathrm{Br}, 2 \mathrm{H}\right), 3.3-3.23$ (m, -CONHCH,$\left.- 2 \mathrm{H}\right), 1.56-$ $1.48\left(\mathrm{~m}, \mathrm{NHCH}_{2} \mathrm{CH}_{2} \mathrm{C}_{8} \mathrm{H}_{17}, 2 \mathrm{H}\right), 1.33-1.21\left(\mathrm{~m},-\mathrm{CH}_{2}\left(\mathrm{CH}_{2}\right)_{7} \mathrm{CH}_{3}, 14 \mathrm{H}\right), 0.86\left(\mathrm{t},-\mathrm{CH}_{2} \mathrm{CH}_{2} \mathrm{CH}_{3}, 3 \mathrm{H}\right)$. HRMS m/z: $278.1111\left((\mathrm{M}+\mathrm{H})^{+}\right.$, observed), 278.1120 (calculated)

Synthesis of 3-((tert-butoxycarbonyl)amino)- $N$-(2-(decylamino)-2-oxoethyl)- $N, N$-dimethylpropan-1-aminium bromide (1b): Compound 1a (2 equivalent) was dissolved in $10 \mathrm{~mL}$ of dry chloroform in a sealed tube and NHBoc- $N, N$-dimethyl propylamine (1 $\mathrm{g}, 1$ equivalent) was added to it. The reaction mixture was refluxed for $48 \mathrm{~h}$. The pure products were purified by column chromatography $\left(\mathrm{CHCl}_{3} / \mathrm{CH}_{3} \mathrm{OH}\right)$ using Silica gel to afford quaternized derivative with yield of $68 \%$.

${ }^{1} \mathrm{H}-\mathrm{NMR}\left(400 \mathrm{MHz}, \mathrm{CDCl}_{3}\right.$ ) $\delta / \mathrm{ppm}: 8.86$ (bs, $\left.-\mathrm{CONH} \mathrm{C}{ }_{10} \mathrm{H}_{21}, 1 \mathrm{H}\right), 5.15$ (s, - $\left.\mathrm{NHBoc}, 1 \mathrm{H}\right), 4.55\left(\mathrm{~s},-\mathrm{N}^{+}\left(\mathrm{CH}_{3}\right)_{2}-\mathrm{CH}_{2} \mathrm{CONHC}_{10} \mathrm{H}_{21}, 2 \mathrm{H}\right)$, 3.67 (t, - BocNHCH$\left.{ }_{2} \mathrm{CH}_{2} \mathrm{~N}^{+}\left(\mathrm{CH}_{3}\right)_{2}-, 2 \mathrm{H}\right), 3.35\left(\mathrm{~s}, \mathrm{~N}^{+}\left(\mathrm{CH}_{3}\right)_{2}, 6 \mathrm{H}\right), 3.29-3.24\left(\mathrm{~m},-\mathrm{CONH}_{-} \mathrm{CH}_{2} \mathrm{CH}_{2^{-}}, 4 \mathrm{H}\right), 2.14-2.11(\mathrm{~m},-$ $\left.\mathrm{N}^{+} \mathrm{CH}_{2} \mathrm{CH}_{2} \mathrm{CH}_{2} \mathrm{NHBOC}_{-}, 2 \mathrm{H}\right), 1.6-1.54\left(\mathrm{~m},-\mathrm{CONHCH} \mathrm{CH}_{2} \mathrm{C}_{8} \mathrm{H}_{17}, 2 \mathrm{H}\right), 1.43$ (s, - $\left.\mathrm{CO}-\mathrm{O}-\mathrm{C}\left(\mathrm{CH}_{3}\right)_{3}, 9 \mathrm{H}\right), 1.25$ (bs, - $\left.\left(\mathrm{CH}_{2}\right)_{7} \mathrm{CH}_{3}, 14 \mathrm{H}\right)$, 0.87 (t, $-\mathrm{CH}_{2} \mathrm{CH}_{2}-\mathrm{CH}_{3}, 3 \mathrm{H}$ ). HRMS m/z: 400.3576 (M+observed), 400.3534 (calculated).

Synthesis of 3-Amino- N,N-dimethyl-N-(2-oxo-2-(decylamino)ethyl)propan-1-aminium chloride (1c): Compound 1b was dissolved in $3 \mathrm{~mL}$ of $1: 1$ solution of $4 \mathrm{~N} \mathrm{HCl}$ and methanol. The reaction mixture was allowed to stir at room temperature for $4 \mathrm{~h}$. The solvents were then evaporated under reduced pressure to obtain pure product in quantitative yield.

${ }^{1} \mathrm{H}-\mathrm{NMR}\left(400 \mathrm{MHz}\right.$, DMSO-d6) $\delta / p p m: 8.76\left(\mathrm{t},-\mathrm{CONHC}_{10} \mathrm{H}_{21}, 1 \mathrm{H}\right), 8.19\left(\mathrm{bs},-\mathrm{NH}_{2}, 2 \mathrm{H}\right), 4.15\left(\mathrm{~s},-\mathrm{N}^{+}\left(\mathrm{CH}_{3}\right)_{2}-\mathrm{CH}_{2} \mathrm{CONHC}_{10} \mathrm{H}_{21}, 2 \mathrm{H}\right)$, 3.72-3.58 (m, ... $\left.\left(\mathrm{CH}_{2}\right)_{2} \mathrm{CH}_{2} \mathrm{~N}^{+}\left(\mathrm{CH}_{3}\right)_{2}^{-}, 2 \mathrm{H}\right), 3.24\left(\mathrm{~s},-\mathrm{N}^{+}\left(\mathrm{CH}_{3}\right)_{2}, 6 \mathrm{H}\right), 3.17-3.1\left(\mathrm{~m},-\mathrm{CONHCH}_{2} \mathrm{C}_{9} \mathrm{H}_{19}, 2 \mathrm{H}\right), 2.89\left(\mathrm{t}, \mathrm{NH}_{2} \mathrm{CH}_{2^{-}}, 2 \mathrm{H}\right), 2.14-$ $2.03\left(\mathrm{~m},-\mathrm{N}^{+} \mathrm{CH}_{2} \mathrm{CH}_{2} \mathrm{CH}_{2} \mathrm{NH}_{2}, 2 \mathrm{H}\right), 1.56-1.51\left(\mathrm{~m},-\mathrm{CONHCH}_{2} \mathrm{CH}_{2} \mathrm{C}_{8} \mathrm{H}_{17}, 2 \mathrm{H}\right), 1.278$ (bs, - $\left.\left(\mathrm{CH}_{2}\right)_{7} \mathrm{CH}_{3}, 14 \mathrm{H}\right), 0.89\left(\mathrm{t}, \mathrm{CH}_{2} \mathrm{CH}_{2}-\mathrm{CH}_{3}\right.$, $3 \mathrm{H}$ ). HRMS m/z: 300.3011 ( $\mathrm{M}^{+}$observed), 300.301 (calculated).

Synthesis of VanQAmC ${ }_{10}$ : Vancomycin hydrochloride (50 mg, 1 equivalent) was dissolved in $1 \mathrm{~mL}$ 1:1 DMSO:DMF. The reaction mixture was cooled to $0{ }^{\circ} \mathrm{C}$, and $0.125 \mathrm{~mL}$ (1.5 equivalents) of $0.45 \mathrm{M}$ HBTU solution in DMF and $25 \mu \mathrm{L}$ (5.0 equivalents) of diisopropylethylamine (DIPEA) were added to the reaction mixture. Two equivalents of compound 1c was dissolved in $1 \mathrm{~mL} 1: 1$ DMSO:DMF and added to the reaction mixture. The reaction was then allowed to continue at room temperature and stirred for $12 \mathrm{~h}$. The product was purified by preparative reverse-phase HPLC using $0.1 \%$ trifluoroacetic acid in $\mathrm{H}_{2} \mathrm{O} /$ acetonitrile mixture and then lyophilized to afford tris-(trifluoroacetate) salt of final compound with yield of $70 \%$ ( $90 \%$ purity).

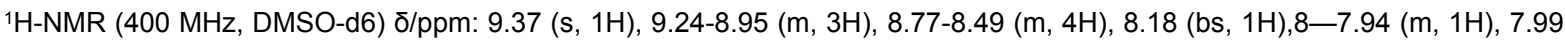
(s, 1H), $7.82(\mathrm{bs}, 2 \mathrm{H}), 7.68(\mathrm{~m}, 3 \mathrm{H}), 7.59-7.44(\mathrm{~m}, 3 \mathrm{H}), 7.38-7.28(\mathrm{~m}, 2 \mathrm{H}), 7.2(\mathrm{~d}, 1 \mathrm{H}), 7.05(\mathrm{~s}, 1 \mathrm{H}), 6.91(\mathrm{~d}, 1 \mathrm{H}), 6.78(\mathrm{~d}, 1 \mathrm{H}), 6.7$ $(\mathrm{d}, 1 \mathrm{H}), 6.39-6.37(\mathrm{~d}, 1 \mathrm{H}), 6.23-6.21(\mathrm{~d}, 1 \mathrm{H}), 6.01-5.97(\mathrm{~s}, 1 \mathrm{H}), 5.85(\mathrm{~s}, 1 \mathrm{H}), 5.76(\mathrm{~d}, 1 \mathrm{H}), 5.59(\mathrm{~s}, 1 \mathrm{H}), 5.47(\mathrm{~s}, 1 \mathrm{H}), 5.4-5.17(\mathrm{~m}$, $5 \mathrm{H}), 4.94(\mathrm{~d}, 1 \mathrm{H}), 4.69(\mathrm{~d}, 1 \mathrm{H}), 4.52-4.47(\mathrm{~d}, 1 \mathrm{H}), 4.27(\mathrm{~d}, 2 \mathrm{H}), 4.07-3.89(\mathrm{~m}, 3 \mathrm{H}), 3.67(\mathrm{~d}, 1 \mathrm{H}), 3.54(\mathrm{~d}, 3 \mathrm{H}), 3.28(\mathrm{bs}, 2 \mathrm{H}), 3.18$ $(\mathrm{s}, 3 \mathrm{H}), 3.12(\mathrm{~s}, 7 \mathrm{H}), 2.9-2.83(\mathrm{~m}, 1 \mathrm{H}), 2.65(\mathrm{~s}, 2 \mathrm{H}), 2.50-2.48(\mathrm{~m}, 13 \mathrm{H}), 2.2-2.12(\mathrm{~m}, 1 \mathrm{H}), 2.04-1.96(\mathrm{~m}, 1 \mathrm{H}), 1.95-1.8(\mathrm{~m}, 2 \mathrm{H})$, 1.76-1.53 (m, 3H), 1.45-1.38 (m, 2H), 1.32-1.29 (m, 2H), 1.26-1.22 (m, 14H), 1.08-1.05 (d, 2H), 0.92-0.83 (m, 9H). HRMS m/z: Observed: $1731.7134\left(\mathrm{M}^{+}\right), 866.3622,(\mathrm{M}+\mathrm{H})^{2+}$; Calculated: $1731.74\left(\mathrm{M}^{+}\right), 866.3704(\mathrm{M}+\mathrm{H})^{2+}$.

${ }^{1} \mathrm{HNMR}$ of $\operatorname{VanQAmC}{ }_{10}$ 


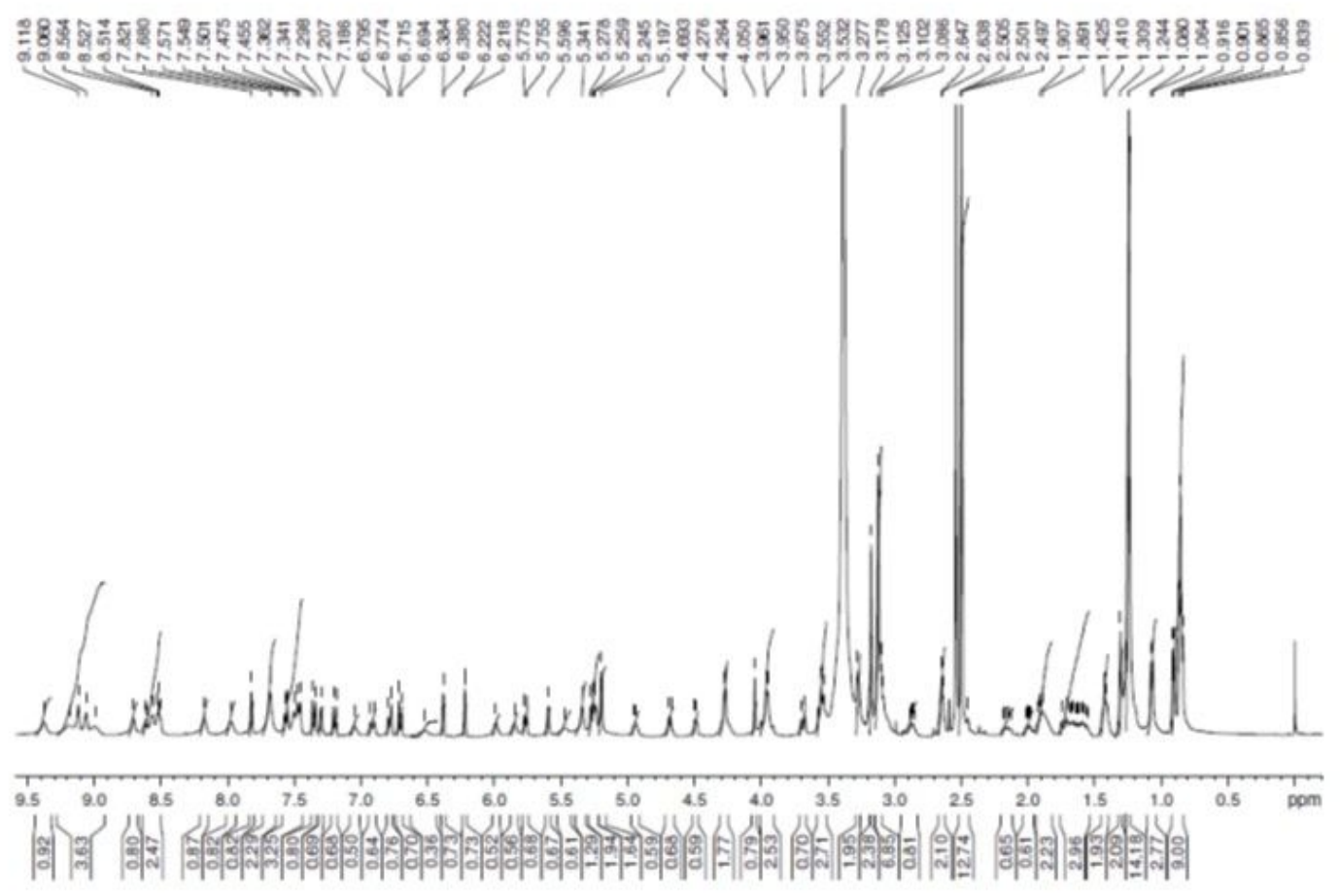

${ }^{13} \mathrm{CNMR}(800 \mathrm{MHz}$, D2O) $\delta / \mathrm{ppm}: 174.764,172.18,165.73,165.264,165.0881,164.912,164.736,159.1858,157.8211$, 156.7366, 142.845, 138.478, 137.5095, 136.498, 130.365, 129.255, 126.8414, 125.8453, 123.4099, 120.68, 120.257, 119.878 , 119.229, 117.77, 116.327, 109.409, 105.7024, 100.107, 79.99, 79.829, 79.667, 78.217, 73.72, 73.16, 71.38, 66.26, 65.282, $64.343,62.77,61.392,60.834,56.90,56.3,54.297,43.797,41.982,40.953,38.674,35.241,34.05,33.439,30.94,30.91,30.73$, $30.548,30.206,28.303,26.078,24.579,24.39,24.29,23.07,19.98,18.49,15.83,15.69$

${ }^{13} \mathrm{CNMR}$ of $\mathrm{VanQAmC} \mathrm{C}_{10}$

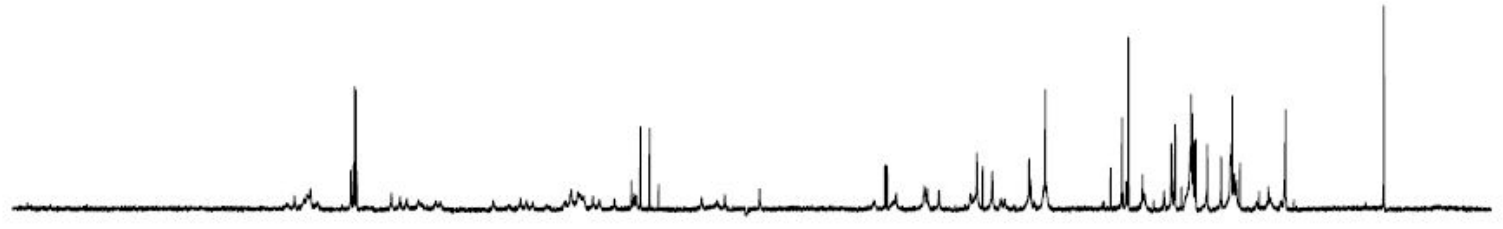




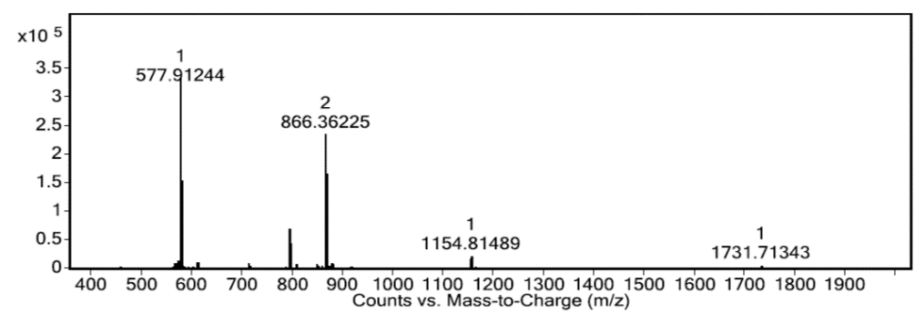

Analytical HPLC of VanQAmC 10

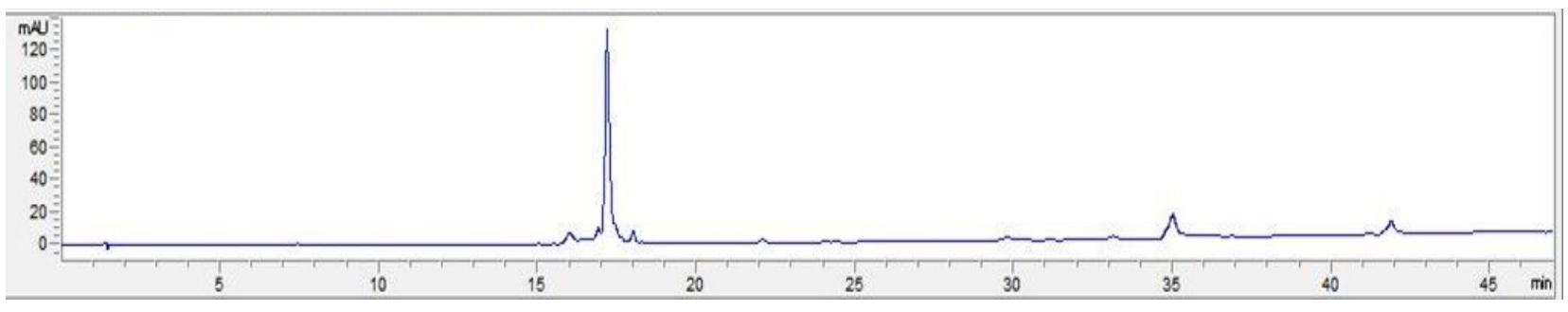

$\sim 90 \%$ purity

\section{Biological assays}

\section{Antibacterial assay: MIC determination ${ }^{1}$}

Test compound was assayed in a micro-dilution broth format as per the CLSI guideline. The bacterial freeze dried stock samples were stored at $-80^{\circ} \mathrm{C}$. About $5 \mu \mathrm{L}$ of these stocks were added to $3 \mathrm{~mL}$ of the respective broth and the culture was grown for $6 \mathrm{~h}$ at $37^{\circ} \mathrm{C}$ with prior to the experiments. This $6 \mathrm{~h}$ grown culture was diluted to give effective cell concentration of $10^{5} \mathrm{CFU} / \mathrm{mL}$ which was then used for determining MIC. Compounds were serially diluted 2-fold, in sterile millipore water and $50 \mu \mathrm{L}$ of these serial dilutions were added to the wells of 96 well plate followed by the addition of about $150 \mu \mathrm{L}$ of bacterial solution. The plates were then incubated for $18-24 \mathrm{~h}$ at $37^{\circ} \mathrm{C}$. The O.D. value at $600 \mathrm{~nm}$ was recorded using TECAN (Infinite series, M200 pro) Plate Reader. Each concentration had triplicate values and the whole experiment was done at least twice and the MIC value was determined by taking the average of triplicate O. D. values for each concentration and plotting it against concentration. The data was then subjected to sigmoidal fitting. From the curve the MIC value was determined, as the point where the O. D. was similar to that of control having no bacteria.

\section{Haemolysis assay ${ }^{2}$}

$50 \mu \mathrm{L}$ of serially diluted compound was added into 96 well microtiter plates. Freshly drawn, heparanized human blood was centrifuged down to obtain the erythrocytes and re-suspended to $5 \mathrm{vol} \%$ in PBS (pH 7.4). $150 \mu \mathrm{L}$ of the erythrocyte suspension was added to the serially diluted compounds (from $1000 \mu \mathrm{M}$ to $2 \mu \mathrm{M}$ ). One set without compound and other with $50 \mu \mathrm{L}$ of $1 \mathrm{vol}$ $\%$ solution of Triton X-100 were kept as controls. The plates were incubated at $37^{\circ} \mathrm{C}$ for $1 \mathrm{~h}$ followed by centrifugation at 3,500 $\mathrm{rpm}$ for $5 \mathrm{~min} .100 \mu \mathrm{L}$ of the supernatant from each well were transferred into fresh microtiter plates, and $A_{540}$ was measured. Percentage of haemolysis was determined using the formula $\left(A-A_{0}\right) /\left(A_{\text {total }}-A_{0}\right) \times 100$, where $A$ is the absorbance of the test well, $A_{0}$ the absorbance of the negative controls (without compound), and $A_{\text {total }}$ the absorbance of $100 \%$ hemolysis wells (with Triton $\mathrm{X}-100)$, all at $540 \mathrm{~nm}$.

\section{Cytotoxicity of VanQAmC ${ }_{10}$ against RAW 264.7}

Cytotoxicity was assessed against the RAW 264.7 cell line. The cells were grown in a 96-well plate in DMEM media supplemented with $10 \%$ fetal bovine serum and $5 \%$ penicillin-streptomycin until they reached around $70-80 \%$ confluency. The cells were then treated with $\operatorname{VanQAmC}_{10}$ at $62.5 \mu \mathrm{M}$ and microscopic images were taken to visualise the morphology of the cells.

\section{Time-kill kinetics assay}

The bactericidal activity of the compounds was evaluated with the time kill kinetics assay. Briefly, A. baumannii was grown in nutrient media at $37^{\circ} \mathrm{C}$ for $6 \mathrm{~h}$. VanQAmC 10 and vancomycin was added to the bacterial solution $\left(\sim 1.8 \times 10^{5} \mathrm{CFU} / \mathrm{mL}\right)$ with the working concentration of $25 \mu \mathrm{M}$. This was incubated at $37^{\circ} \mathrm{C}$. At different time intervals $(0,1,2,3,6$ and $24 \mathrm{~h}) 20 \mu \mathrm{L}$ of aliquots from that solution were serially diluted 10 -fold in $0.9 \%$ saline. Then from the dilutions, $20 \mu \mathrm{L}$ was plated on yeast-dextrose agar plates and incubated at $37^{\circ} \mathrm{C}$ for $24 \mathrm{~h}$. The bacterial colonies were counted and results are represented in logarithmic scale, i.e. $\log _{10}(\mathrm{CFU} / \mathrm{mL})$.

\section{Inner Membrane permeabilization assay ${ }^{4}$}


The $6 \mathrm{~h}$ grown culture (mid log phase) of $A$. baumannii R674 were harvested (5000 rpm, $5 \mathrm{~min}$ ), washed, and resuspended in 1:1 solution of $5 \mathrm{mM}$ glucose and $5 \mathrm{mM}$ HEPES buffer at $\mathrm{pH}$ 7.2. $10 \mu \mathrm{M}$ of propidium iodide $(\mathrm{PI})$ was added to the bacterial suspension and $200 \mu \mathrm{L}$ of this mixture was put into 96-well flat clear bottomed black well plates. $20 \mu \mathrm{L}$ of test compound and vancomycin were added to it the wells containing bacterial suspension. Fluorescence has monitored at excitation wavelength of $535 \mathrm{~nm}$ (slit width: $10 \mathrm{~nm}$ ) and emission wavelength of $617 \mathrm{~nm}$ (slit width: $5 \mathrm{~nm}$ ). As a measure of inner membrane permeabilization the uptake of PI was monitor by the increase in fluorescence for 30-50 min.

\section{Cytoplasmic membrane depolarization assay ${ }^{4}$}

Mid log phase A. baumannii R674 were harvested (3500 rpm, $5 \mathrm{~min}$ ), washed in $5 \mathrm{mM}$ glucose and $5 \mathrm{mM} \mathrm{HEPES} \mathrm{buffer} \mathrm{(pH} \mathrm{7.2)}$ in 1:1 ratio and resuspended in $5 \mathrm{mM}$ HEPES buffer, $5 \mathrm{mM}$ glucose and $100 \mathrm{mM} \mathrm{KCl}$ solution in 1:1:1 ratio. Then $2 \mu \mathrm{M}$ of $3,3^{\prime}-$ Dipropylthiadicarbocyanine iodide (DiSC3(5)) was added to bacterial suspension and pre-incubated for $45 \mathrm{~min}$. The fluorescence was monitored at excitation wavelength of $622 \mathrm{~nm}$ and emission wavelength of $670 \mathrm{~nm}$. Then $20 \mu \mathrm{L}$ of test compound and vancomycin were added to black well plates containing bacterial suspension and DiSC3(5) after 2-4 min of fluorescence measurement. As a measure of membrane depolarization fluorescence was monitor for another $35 \mathrm{~min}$.

\section{Outer membrane permeabilization assay}

Mid-log phase $A$. baumannii R674 cells were harvested, washed with 1:1 solution of $5 \mathrm{mM}$ HEPES and 5 mM glucose and resuspended in the same to obtain $10^{8} \mathrm{CFU} / \mathrm{mL}$ bacterial suspension. To this solution $\mathrm{N}$-phenylnaphthylamine dye was added to a final concentration of $5 \mu \mathrm{M}$ and $200 \mu \mathrm{L}$ of the mixture was put into flat clear bottomed black well plates. Fluorescence readings were taken for 4 minutes before the addition of compounds. $20 \mu \mathrm{L}$ of test compounds (vancomycin, VanQAmC ${ }_{10}$ ) were added to the bacterial suspension at the required concentration. After addition, the fluorescence intensity (excitation wavelength: $350 \mathrm{~nm}$; emission wavelength: $420 \mathrm{~nm}$ ) was measured for 10 minutes.

\section{Scanning Electron Microscopy ${ }^{5}$}

A. baumannii R674 cells were grown to mid-log phase and treated with $50 \mu \mathrm{M} V a n Q A m C_{10}$. The bacterial suspension was then centrifuged and the pellet was washed once with PBS and resuspended in $30 \%$ ethanol. Further the cells were sequentially washed with $50 \%, 70 \%, 90 \%$, and $100 \%$ ethanol. The bacteria were resuspended in $90 \%$ ethanol and $5 \mu \mathrm{L}$ of the suspension in ethanol was drop-casted onto silicon wafer. The wafer was dried in air at room temperature. Quanta 3D FEG, FEI scanning electron microscope was used to image the bacterial samples which were coated with gold prior to imaging.

\section{Antibacterial activity against stationary phase $A$. baumannii}

A. baumannii MTCC1425 was grown to mid-log phase at $37^{\circ} \mathrm{C}$. The bacterial suspension was diluted 1000 fold in LB media and allowed to reach stationary phase in $16 \mathrm{~h}$. The bacterial suspension was diluted and spot-plated Mac Conkey agar to determine the bacterial count. The $16 \mathrm{~h}$ growth culture was diluted to $\sim 10^{6} \mathrm{CFU} / \mathrm{mL}$ in PBS. $150 \mu \mathrm{L}$ of this bacterial suspension was then incubated with $50 \mu \mathrm{L}$ of test compounds in a 96 well-plate. The compound and bacteria were then incubated at $37^{\circ} \mathrm{C}$ for $2 \mathrm{~h}$. The suspension was serially diluted 10 fold and spot-plated on Mac Conkey agar. The viable bacteria were then counted after $48 \mathrm{~h}$ incubation at $37^{\circ} \mathrm{C}$. The results represented are the average of two independent experiments carried in duplicates.

\section{Mechanism of action against stationary phase bacteria}

Stationary phase $A$. baumannii MTCC1425 cells were grown and the depolarisation, inner membrane and outer membrane permeabilisation assays as described earlier were performed.

\section{Cell wall biosynthesis inhibition assay ${ }^{2}$}

Cytoplasmic accumulation of peptidoglycan precursor was examined using A. baumannii R674 cells grown in $24 \mathrm{~mL} M H$ Broth. Cells were grown to an absorbance at $600 \mathrm{~nm}\left(\mathrm{OD}_{600}\right)$ of 0.6 and incubated with $130 \mu \mathrm{g} / \mathrm{mL}$ of chloramphenicol for $15 \mathrm{~min}$. Then, test compounds vancomycin $(5 \mu \mathrm{M}), \operatorname{VanQAmC}_{10}(7 \mu \mathrm{M}, 35 \mu \mathrm{M}$ and $70 \mu \mathrm{M})$ were added and incubated for another 60 min. Cells were collected and washed with sterile water to remove the antimicrobial agents and then resuspended in boiling water. This was then heat treated for $1 \mathrm{~h}$ to lyse the cells. The cell extract was then centrifuged and the supernatant lyophilized. Then, the lyophilized product was dissolved in $2 \mathrm{~mL}$ of water whose $\mathrm{pH}$ was adjusted to 2.0 with $20 \%$ phosphoric acid. The UDP-linked cell wall precursors in the solution were analysed by RP-HPLC monitoring the UV absorbance peak at $260 \mathrm{~nm}$ wavelength and confirmed by HR-MS mass spectrometry.

\section{Resistance study ${ }^{2}$}

The initial MIC values of $\mathrm{VanQAmC}_{10}$ and colistin were determined against $A$. baumannii $\mathrm{R} 674$. After the initial MIC experiment, serial passaging was initiated by harvesting bacterial cells growing in the sub-MIC concentration of the compounds (at MIC/2) and was subjected to another MIC assay. The bacterial concentration was adjusted to $\sim 10^{5} \mathrm{CFU} / \mathrm{mL}$ based on $\mathrm{OD}_{600}$. The process was repeated for 19 passages. The fold of MIC increased for test compound and control antibiotics were plotted against the number of days.

\section{Biofilm disruption assays}

Confocal laser scanning microscopy ${ }^{6}$ 
Glass cover slips (diameter $13 \mathrm{~mm}$ ) were sterilised and placed individually in 6-well plates. Mid-log phase A. baumannii was diluted to $\sim 10^{5} \mathrm{CFU} / \mathrm{mL}$ in BM2 media which was supplemented with $0.5 \%$ glucose as carbon source, $0.5 \%$ casamino acids and $200 \mu \mathrm{M} \mathrm{FeCl}{ }_{3}$. Cover slips were then incubated with $2 \mathrm{~mL}$ of the above bacterial suspension under stationary conditions at 30 ${ }^{\circ} \mathrm{C}$, for $48 \mathrm{~h}$. After $48 \mathrm{~h}$ the cover slips were removed and carefully washed with $0.9 \%$ saline to remove planktonic bacteria. The biofilm containing cover-slips were then taken into a fresh well and treated with $2 \mathrm{~mL}$ complete BM2 media containing the test compounds the required concentrations. $24 \mathrm{~h}$ post- treatment, the cover slips were taken out and washed in $0.9 \%$ saline. The cover slips were then stained with $3 \mu \mathrm{M}$ SYTO-9 dye and imaged using a Zeiss 510 Meta confocal laser-scanning microscope. The orthogonal projections of the images were processed with LSM 5 Image examiner.

\section{Cell viability of bacteria in biofilms ${ }^{7}$}

Biofilms of $A$. baumannii R674 were grown and treated with test compounds as described above. Post-treatment, the biofilm containing cover slips were treated with trypsin-EDTA for $20 \mathrm{~min}$ at $37^{\circ} \mathrm{C}$, serially diluted ten-fold and plated on MacConkey agar. The count of viable bacterial cells was taken $24 \mathrm{~h}$ after incubation. The results represented are the average of three independent experiments carried in duplicates.

\section{In-vivo toxicity ${ }^{2}$}

Systemic toxicity was examined after intravenous (i.v) injection of $\mathrm{VanQAmC}_{10}$ to groups of five Balb/c female mice. Each mouse was injected with a $0.2 \mathrm{~mL}$ of freshly prepared compound solution in saline. The doses for i.v. administration, were $179 \mathrm{mg} / \mathrm{kg}$, $55.5 \mathrm{mg} / \mathrm{kg}, 17.5 \mathrm{mg} / \mathrm{kg}$ according to OECD guidelines. Animals were directly inspected for adverse effects for $4 \mathrm{~h}$, and mortality was observed for 14 days, thereafter, $\mathrm{LD}_{50}$ was determined using Spearman-Karber method. All the mice died upon treatment at $179 \mathrm{mg} / \mathrm{kg}$ and one mouse died in the $55.5 \mathrm{mg} / \mathrm{kg}$ treatment group.

\section{Intracellular antibacterial activity against MRSA ${ }^{8}$}

RAW 264.7 cells were seeded in 24-well tissue culture plates containing complete growth medium at $37^{\circ} \mathrm{C}$ in humidified air containing $5 \% \mathrm{CO}_{2}$ for $12 \mathrm{~h}$ to allow cell adherence. MRSA cells $\left(\sim 10^{7} \mathrm{CFU} / \mathrm{mL}\right)$ were suspended in complete growth medium for $1 \mathrm{~h}$ to allow opsonisation. Wells containing RAW 264.7 cells were incubated with $500 \mu \mathrm{L}$ of the opsonised bacterial suspension for $1.5 \mathrm{~h}$ at $37{ }^{\circ} \mathrm{C}$ in humidified air containing $5 \% \mathrm{CO}_{2}$ to allow phagocytosis (adjusted to an $\mathrm{MOI}$ of 4 ). Next, the macrophages were washed twice with phosphate-buffered saline (PBS) at $\mathrm{pH}=7.2$ and treated with $50 \mu \mathrm{g} / \mathrm{mL}$ of gentamicin for $1 \mathrm{~h}$ in complete growth medium in order to remove any extracellular or non-phagocytosed bacteria. RAW 264.7 macrophages were then washed twice with PBS to remove the gentamicin. $500 \mu \mathrm{L}$ of growth medium containing test compounds at $100 \mathrm{X}$ MIC (vancomycin at 60 $\mu \mathrm{M}$ and $V_{a n Q A m C} 10$ at $40 \mu \mathrm{M}$ ) were added and the cells and incubated at $37^{\circ} \mathrm{C}$ in humidified air containing $5 \% \mathrm{CO}_{2}$ for $6 \mathrm{~h}$ and $12 \mathrm{~h}$. The cells were then lysed by treating with $500 \mu \mathrm{L}$ of ice cold water for $1 \mathrm{~h}$ and the lysates were then collected, centrifuged and resuspended in 1X PBS. Lysates were serially diluted 10-fold and plated on nutrient agar. The plates were then incubated at $37^{\circ} \mathrm{C}$ for $24 \mathrm{~h}$ and the viable bacterial colonies were counted. The results represented are the average of three independent experiments carried in duplicates.

\section{Tandem mRFP-GFP-LC3 assay}

HeLa cells were cultured in Dulbecco's modified Eagle's medium supplemented with $8 \%$ heat-inactivated fetal bovine serum on cover slips. Transfection was performed using LipofectAMINE3000 according to the manufacturer's protocol and the tandem mRFP-GFP-LC3 plasmid was allowed to express for $24 \mathrm{~h} .{ }^{9}$ The cells were then treated with $1 \mathrm{~mL}$ of compounds at $100 \mu \mathrm{M}$ for $2 \mathrm{~h}$. The slides were then mounted with Vecta shield and imaged through GFP and RFP channels and counting was done with ImgaeJ software. The results represented are the average of three independent experiments carried in duplicates.

\section{Intracellular anti-bacterial activity against Salmonella typhimurium}

HeLa cells were seeded in 24-well tissue culture plates containing complete growth medium at $37^{\circ} \mathrm{C}$ in humidified air containing $5 \% \mathrm{CO}_{2}$ for $12 \mathrm{~h}$ to allow cell adherence. Late log phase wild-type bacteria were grown for $16 \mathrm{~h}$ at $37^{\circ} \mathrm{C}$ with shaking and then subcultured (1:33) in LB for 3h. Bacterial inoculum was pelleted and diluted 1:100 in PBS, pH 7.2, and added to the cells for $1 \mathrm{~h}$. The cells were then treated with $50 \mu \mathrm{g} / \mathrm{mL}$ gentamycin. Compounds were then added to the well containing infected cell and incubated for $4 \mathrm{~h}$. The cells were lysed with $1: 10.1 \%$ triton $X$ and $0.1 \%$ SDS in PBS. The samples were serially diluted 10 -fold and plated. The results represented are the average of three independent experiments carried in duplicates.

\section{Results}

Figure S1: Mechanism of action of VanQAmC ${ }_{10}$ against exponential phase bacteria (A) Outer membrane permeabilization (B) Inner membrane permeabilization (C) Membrane depolarisation 

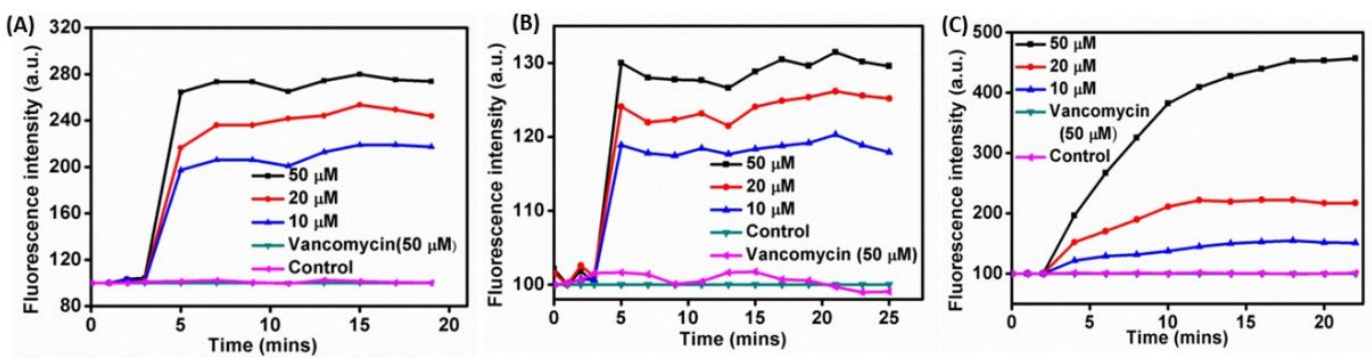

The increase in fluorescence in each of the graphs, indicates that VanQAmC ${ }_{10}$ dissipated the membrane potential and permeabilised both the outer and inner membranes in a concentration dependent manner.

Figure S2: Mechanism of action of VanQAmC ${ }_{10}$ against stationary phase bacteria $A$. baumannii (A) Outer membrane permeabilization (B) Inner membrane permeabilization (C) Membrane depolarisation
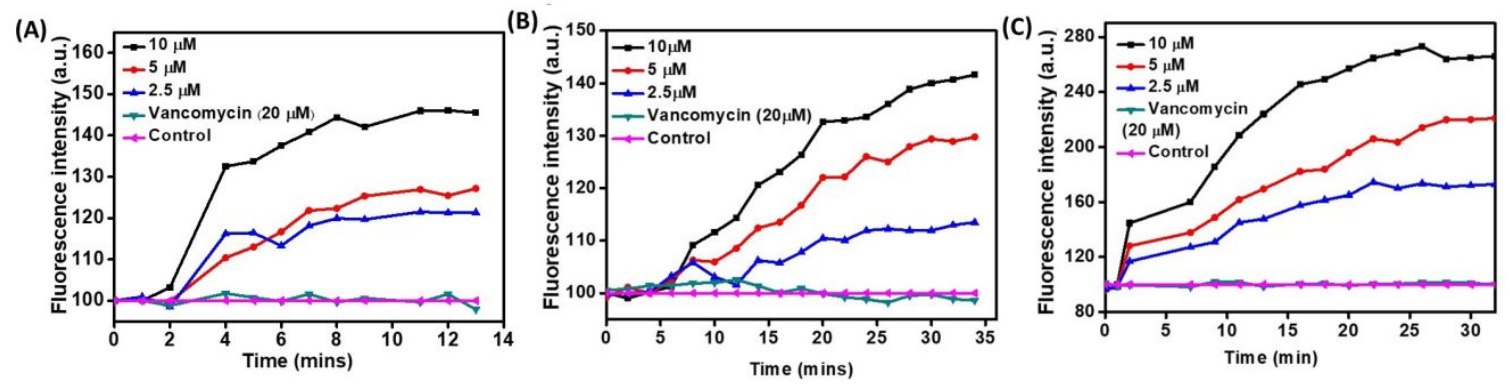

Figure S3: Propensity of VanQAmC ${ }_{10}$ to induce resistance in $A$. baumannii

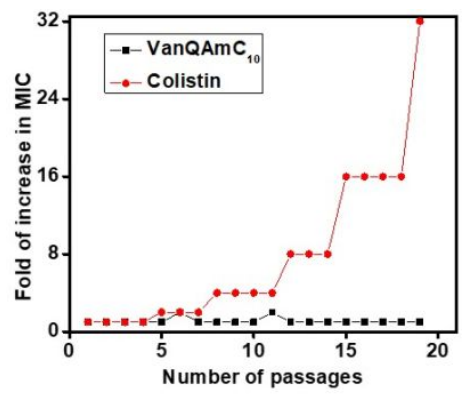

Fig S4: Determination of $\%$ Hemolysis of VanQAmC ${ }_{10}$

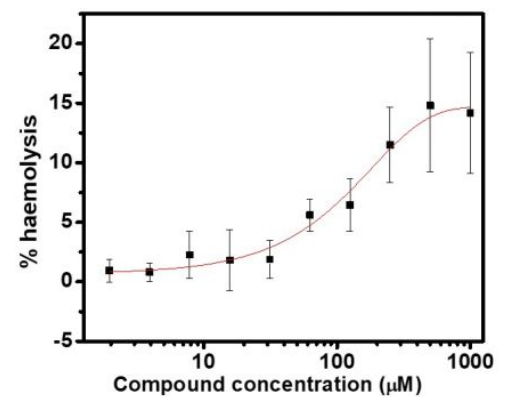

$\mathrm{HC}_{50}$ of VanQAmC $\mathrm{C}_{10}$ was found to be greater than $1000 \mu \mathrm{M}$

Fig S5: Representative phase-contrast microscopic images of RAW 264.7 cell line after treatment with VanQAmC Vat $_{10}$ at $62.5 \mu \mathrm{M}$ 

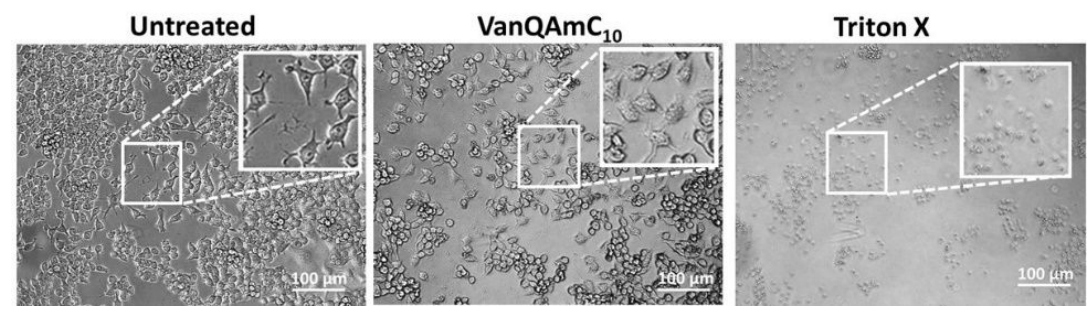

Images were taken at 20X zoom.

The morphology of the RAW 264.7 cells were found to be unchanged upon treatment with VanQAmC ${ }_{10}$.

Table S1: Antibacterial activity of VanQAmC 10 against multidrug-resistant Gram-negative bacteria

\begin{tabular}{ll}
\hline Bacterial Strain & MIC $(\mu \mathrm{M})$ \\
\hline E. coli MTCC 443 & 12.5 \\
E. coli MTCC 448 & 25 \\
E. cloacae R 2928 & $>100$ \\
K. pneumoniae MTCC 700603 & $>100$ \\
P. aeruginosa R 590 & 12.5 \\
$P$. aeruginosa MTCC 424 & $>100$ \\
\hline
\end{tabular}

\section{References}

1. Wiegand, I., Hilpert, K., and Hancock, R. E. (2008) Agar and broth dilution methods to determine the minimal inhibitory concentration (MIC) of antimicrobial substances, Nat Protoc 3, 163-175.

2. Yarlagadda, V., Manjunath, G. B., Sarkar, P., Akkapeddi, P., Paramanandham, K., Shome, B. R., Ravikumar, R., and Haldar, J. (2015) Glycopeptide Antibiotic To Overcome the Intrinsic Resistance of Gram-Negative Bacteria, ACS Infect. Dis.

3. Yarlagadda, V., Akkapeddi, P., Manjunath, G. B., and Haldar, J. (2014) Membrane active vancomycin analogues: a strategy to combat bacterial resistance, J. Med. Chem. 57, 4558-4568.

4. Ghosh, C., Manjunath, G. B., Akkapeddi, P., Yarlagadda, V., Hoque, J., Uppu, D. S., Konai, M. M., and Haldar, J. (2014) Small molecular antibacterial peptoid mimics: the simpler the better!, J. Med. Chem. 57, 1428-1436.

5. Hoque, J., Akkapeddi, P., Ghosh, C., Uppu, D. S., and Haldar, J. (2016) A Biodegradable Polycationic Paint that Kills Bacteria in Vitro and in Vivo, ACS Appl Mater Interfaces 8, 29298-29309.

6. Lebeaux, D., Chauhan, A., Rendueles, O., and Beloin, C. (2013) From in vitro to in vivo models of bacterial biofilm-related infections, Pathogens $2,288-356$

7. Uppu, D. S., Samaddar, S., Ghosh, C., Paramanandham, K., Shome, B. R., and Haldar, J. (2016) Amide side chain amphiphilic polymers disrupt surface established bacterial bio-films and protect mice from chronic Acinetobacter baumannii infection, Biomaterials 74, $131-143$.

8. Yarlagadda, V., Samaddar, S., and Haldar, J. (2016) Intracellular activity of a membrane-active glycopeptide antibiotic against meticillin-resistant Staphylococcus aureus infection, J. Glob. Antimicrob. Resist.

9. Kimura, S., Noda, T., and Yoshimori, T. (2007) Dissection of the autophagosome maturation process by a novel reporter protein, tandem fluorescent-tagged LC3, Autophagy 3, 452-460.

\section{Author Contributions}

Paramita Sarkar- Project design, Experimental design and Investigation (synthesis, characterization, in-vitro and in-vivo biological assays), Data curation, Analysis, Manuscript writing

Sandip Samaddar- Experimental Investigation intracellular assay and analysis, Manuscript preparation

Chandradhish Ghosh - Intracellular assay, Manuscript preparation

Veena Ammanathan and Ravi Manjithaya- Autophagy, Tandem mRFP-GFP-LC3 assay and analysis, Manuscript preparation

Venkateswarlu Yarlagadda- In-vivo $\mathrm{LD}_{50}$ determination, Manuscript preparation

Manjulika Shukla, Grace Kaul and Sidharth Chopra- MIC determination against various clinical isolates of $A$. baumannii, Manuscript preparation

Jayanta Haldar- Project design, Experimental design, Data analysis, Manuscript writing 